Doi: $10.4274 /$ vhd.0010

Viral Hepatitis Journal 2018;24(1):7-11

\title{
Seroprevalence of Hepatitis B Surface Antigen, Anti-Hepatitis $B$ Surface and Anti-Hepatitis C Virus Among Pregnant Women Residing in Șırnak Province
}

\author{
Șırnak Ilinde Yașayan Gebelerdeki Hepatit B Yüzey Antijeni, Anti-Hepatit B Yüzey ve \\ Anti-Hepatit C Virüsü Seroprevalansı
}

\section{• Meyha ŞAHIN¹, ๑ Meltem ZENCIR¹, • Alper Akın GÖZÜBÜYÜK², • Bedri Aras PEKTAŞ33}

${ }^{1}$ Şırnak State Hospital, Clinic of Infectious Diseases and Clinical Microbiology, Şırnak, Turkey

${ }^{2}$ Cizre State Hospital, Clinic of Infectious Diseases and Clinical Microbiology, Şırnak, Turkey

3Şırnak State Hospital, Clinic of Obstetrcis and Gynecology, Şırnak, Turkey

\begin{abstract}
Objectives: The purpose of the study was to detect the rate of hepatitis B surface antigen (HBsAg), anti-HBs and anti-hepatitis C virus (HCV) seropositivity among pregnant women residing in the city of Şırnak.

Materials and Methods: Results of serological tests for HBsAg, anti$\mathrm{HBs}$ and anti-HCV in 2214 pregnant women, who were admitted to the Gynecology and Obstetrics Clinics and Emergency Departments at Şrnak State Hospital and Cizre State Hospital between the dates of April 1, and October 1, 2017, were retrospectively evaluated. Results: A total of 2214 pregnant women were included in this study. It was determined that the rate of seropositivity for HBsAg, anti-HBs and anti-HCV was $1 \%, 27.8 \%$, and $0.21 \%$, respectively. It was found that anti-HBs seropositivity rate among pregnant women younger than 19 years was $54.5 \%$, which was higher than in those aged 19 years or older.

Conclusion: Anti-HCV positivity rate detected in pregnant women who resided in Şırnak was found to be similar to the results reported in other studies conducted in our country, however, HBsAg positivity rate was found to be lower when compared with the results of other studies. A significant increase was detected in anti-HBs seropositivity rate in Şırnak since hepatitis B vaccine was included in the national immunization schedule.

Keywords: Pregnancy, hepatitis B surface antigen, anti-hepatitis C virus, anti-hepatitis B surface, seroprevalence
\end{abstract}

\section{$0 ̈ Z$}

Amaç: Bu çalışmada Şırnak ilinde yaşayan gebelerde, hepatit B yüzey antijeni (HBsAg), anti-HBs ve anti-hepatit C virüsü seropozitiflik oranlarııı saptanması amaçlanmıştır.

Gereç ve Yöntemler: Şırnak Devlet Hastanesi ve Cizre Devlet Hastanesi'nin Kadın Hastalıkları ve Doğum Poliklinikleri ile Acil Servisleri'ne 1 Nisan-1 Ekim 2017 tarihleri arasında başvuran 2214 gebe kadının HBsAg, anti-HBs ve anti-HCV verileri retrospektif olarak incelendi ve sonuçlar kayıt altına alındı.

Bulgular: Çalışmaya 2214 gebe dahil edildi. HBsAg seroprevelansı $\% 1$, anti-HBs pozitiflik oranı \%27,8, anti- HCV seroprevelansı \% 0,21 saptandı. On dokuz yaş ve altında olan gebelerde \%54,5 olan antiHBs seropozitiflik oranının, 19 yaş üstü gebelerdekine göre yüksek olması istatistiksel olarak anlamlı bulundu.

Sonuç: Şırnak ilinde yaşayan gebelerde tespit edilen antiHCV pozitiflik oranı ülkemizde yapılan diğer çalışmalara benzer bulunurken, HBsAg pozitiflik oranı ise diğer çalışmalara göre daha düşük bulunmuştur. Hepatit B aşısının ulusal bağışıklama programına girmesi ile Şırnak ilinde anti-HBs seropozitiflik oranında belirgin bir artış olduğu tespit edilmiştir.

Anahtar Kelimeler: Gebelik, hepatit B yüzey antijeni, anti-hepatit C virüsü, anti-hepatit B yüzey, seroprevelans

Şahin M, Zencir M, Gözübüyük AA, Pektaş BA. Seroprevalence of Hepatitis B Surface Antigen, Anti-Hepatitis B Surface and Anti-Hepatitis C Virus Among Pregnant Women Residing in Şırnak Province. Viral Hepat J. 2018;24:7-11.

Address for Correspondence: Meyha Şahin MD, Şırnak State Hospital, Clinic of Infectious Diseases and Clinical Microbiology, Şırnak, Turkey Phone: +90 4862167500 - 2477 E-mail: meyhasahin@hotmail.com ORCID ID: orcid.org/0000-0003-4147-3587 Received: 04.11.2017 Accepted: 08.02.2018 


\section{Introduction}

According to the data of the World Health Organization, 1.34 million people died of viral hepatitis in 2015 , being a figure which is similar to the number of deaths due to tuberculosis and more than death due to human immunodeficiency virus (HIV) infection (1).

In general, more than one third of the existing chronic hepatitis $B$ infections occur as a result of mother-to-child transmission (2). Especially in high endemic regions where hepatitis B surface antigen ( $\mathrm{HBsAg}$ ) prevalence is $\geq 8 \%$, chronic hepatitis B is mostly prevalent in early childhood, and in these regions, mother-to-child transmission is the most significant transmission route $(3,4,5)$. It has been reported that $70-90 \%$ of children born to hepatitis $B$ virus (HBV)-infected mothers were infected and more than $95 \%$ of them were chronic carriers. $(6,7)$. It is known that hepatitis $B$ vaccination and hepatitis $B$ immunoglobulin administration in the first 12 hours of birth can reduce the risk of vertical transmission from $90 \%$ to $5-10 \%$ in children born to HBsAg-positive mothers $(8,9)$.

The risk of mother-to-child transmission of hepatitis $\mathrm{C}$ virus (HCV) infection is $3-10 \%(6,10,11)$. It is estimated that 40.000 children are born to HCV-infected mothers every year, and about 4000 of them are infected with HCV $(12,13)$.

The HBsAg seropositivity rate, which ranges from $1.9 \%$ to $8.4 \%$ in our country, is found to be $4.4 \%$ on average $(6,14)$. The rate of $\mathrm{HCV}$ seroprevalence in the country is reported to be $0.3-$ $1.7 \%(15,16)$.

Since the fertility rate is high in the Şrnak region (17), it is considered that the seroprevalence of these vertically-transmitted infections is important. For this reason, the present study aimed to determine the rate of $\mathrm{HBsAg}$, anti-HBs (hepatitis B surface antibody) and anti-HCV (hepatitis C antibody) seropositivity among pregnant women living in Şırnak.

\section{Materials and Methods}

Results of serological tests for HBsAg, anti-HBs and anti$\mathrm{HCV}$ in 2214 pregnant women, who were admitted to the Obstetrics and Gynecology Clinics and Emergency Departments at Şırnak State Hospital and Cizre State Hospital between April 1 and October 1, 2017, were retrospectively analyzed from the hospitals' information management system. HBsAg II (Roche, Mannheim, Germany), Elecsys anti-HBs II (Roche, Mannheim, Germany) and anti-HCV II (Roche, Mannheim, Germany) were used for these tests in the ELISA laboratory at both hospitals. In this respect, samples with a cut off index $>1$ were considered positive for HBsAg, and anti-HCV; and samples with a cutoff index $>10 \mathrm{IU} / \mathrm{mL}$ were considered positive for anti-HBs.

\section{Statistical Analysis}

Statistical analysis was performed by using the SPSS (version 21.0, Armonk, NY, USA) program. A chi-square test was used to evaluate the data. A p value of less than 0.05 was considered statistically significant.

This study was carried out in accordance with the principles of the Helsinki Declaration.

\section{Results}

The mean age of the 2214 pregnant women was $28.3 \pm 8.26$ (14-46) years. The rates of HBsAg seropositivity, anti-HBs positivity, and anti-HCV seropositivity were found to be $1 \%, 27.8 \%$, and $0.21 \%$, respectively. The seropositivity rates for $\mathrm{HBsAg}$, anti-HBs and anti-HCV according to age groups are shown in Table 1. Three hundred and eighty one (27.8\%) out of 1368 pregnant women were found to be anti-HBs-positive. Anti-HBs positivity rate was $54.5 \%$ in women aged $\leq 19$ years and $26.5 \%$ in those over 19 years of age. The difference was statistically significant $(p<0.001)$.

\section{Discussion}

Vertical transmission of hepatitis B infection to an infant can be prevented greatly by providing vaccination, and immunoglobulin within 12 hours of birth and starting antiviral treatment to the mother with high viremia in the third trimester. For this reason, routine screening for $\mathrm{HBsAg}$ is recommended during pregnancy in the prenatal period $(2,6,8,16)$. Routine prenatal $\mathrm{HCV}$ screening is not recommended because there is no proven vaccine, intervention, or approved treatment to reduce or prevent vertical transmission of HCV infection $(12,18,19)$. In general, screening for HCV infection is recommended for pregnant women having risk factors for hepatitis C, such as HIV infection and intravenous drug use $(12,20)$.

It is known that approximately 5-7 million people in Turkey are active HBV carriers. Carriage rates are reported to be between 4\% and $14 \%$ varying from cities to cities (21). Epidemiological studies covering the whole country in the previous years showed that the rate of HBsAg positivity was lower in the western regions of the country but was significantly higher in the regions of Central Anatolia, Eastern and Southeastern Anatolia (22). In a review published in 2011, HBsAg seroprevalence was found to be $3.47 \%$ in the Aegean and Marmara regions, $4.86 \%$ in the Central Anatolia, Mediterranean and Black Sea regions and $6.72 \%$ in the Eastern and Southeastern Anatolia regions $(23,24)$. In their study covering Diyarbakır, Batman and Şanlıurfa provinces, Dursun et al. (25) have reported that the rate of $\mathrm{HBsAg}$ positivity in city centers was $7.2 \%$ in males and $5.3 \%$ in females. While the rate of HBsAg positivity in Siirt province was determined as 10\% in 2011 (26), it was found to be $12.6 \%$ in a study conducted in Batman in 2012 (27). Besides,

\begin{tabular}{|l|l|l|l|l|}
\hline \multicolumn{5}{|l|}{$\begin{array}{l}\text { Table 1. The rates of hepatitis B surface antigen, anti-hepatitis B surface } \\
\text { and anti-hepatitis C virus seropositivity according to age groups }\end{array}$} \\
\hline $\begin{array}{l}\text { Age } \\
\text { groups }\end{array}$ & $\begin{array}{l}\text { Number } \\
\text { of } \\
\text { patients }\end{array}$ & $\begin{array}{l}\text { Number } \\
\text { of HBsAg- } \\
\text { positive } \\
\text { patients (\%) }\end{array}$ & $\begin{array}{l}\text { Number of anti- } \\
\text { HCV-positive } \\
\text { patients }\end{array}$ & $\begin{array}{l}\text { Anti-HBs positivity } \\
\text { rate (\%) }\end{array}$ \\
\hline$\leq 19$ & 117 & $1(0.8)$ & - & $36 / 66$ (54.5) \\
\hline $20-25$ & 701 & $3(0.4)$ & 1 & $229 / 439(52.2)$ \\
\hline $26-30$ & 637 & $8(1.3)$ & 1 & $57 / 384(14.8)$ \\
\hline $31-35$ & 447 & $3(0.7)$ & 1 & $41 / 280(14.6)$ \\
\hline $36-40$ & 256 & $7(2.7)$ & - & $17 / 161(10.6)$ \\
\hline $41-45$ & 54 & 0 & - & $1 / 36(2.8)$ \\
\hline$\geq 46$ & 2 & 0 & - & $0 / 1$ \\
\hline $\begin{array}{l}\text { HBsAg: Hepatitis B surface antigen, HCV: Hepatitis C virus, HBs: Hepatitis B } \\
\text { surface }\end{array}$
\end{tabular}


there has been a decline in hepatitis B seroprevalence over the years in our country. Ergunay et al. (28) found a significant decrease (from $12.3 \%$ to $5 \%$ ) in the seroprevalence of hepatitis B between 2000 and 2010. An eight-year seroprevalence study performed in Diyarbakır between 2005 and 2012 reported a significant decline (from $15.9 \%$ to $9 \%$ ) in HBsAg positivity over the years (29). The prevalence of HBsAg seropositivity in children examined before elective surgery in Mardin in 2011 was found to be $0.5 \%$ and the most important contribution to this result was suggested to be the vaccination program and preventive measures implemented by the Ministry of Health (30). While HBsAg positivity was found to be $9.6 \%$ in Şanlıurfa during the period of 1998-1999 (31), this rate was found to be $2.9 \%$ in blood donors in another study performed in Şanlıurfa between 2004 and 2006 (32). In Hakkari province, the HBsAg seroprevalence was detected to be $2.7 \%$ in a study conducted in 2006 and it is thought that these low carrier rates can be caused by the fact that Hakkari is a closed and isolated region in terms of both geographical and socioeconomic terms (33). In addition, when we look at the literature, the only study available on the seroprevalence of hepatitis B in Turkey was conducted by Emiroğlu et al. (34) in Şırnak. They studied the prevalence of asymptomatic HBV carriers among soldiers and civilians in Şırnak. The HBsAg positivity rate in this study was determined to be $6.8 \%$. This study was conducted in 1998 and the group of patients was composed of soldiers who came from different regions of the country, therefore, this study cannot exactly reflect the situation in Şırnak province today.

There are also many studies on hepatitis seroprevalence in pregnant women in our country. Bakar and Dane (5) observed that the highest HBsAg seropositivity rate was 9.3\% and the HBsAg seropositivity rate was not higher than $6 \%$ in the studies conducted in the last 7 years when they examined the studies

\begin{tabular}{|c|c|c|c|c|}
\hline & $\begin{array}{l}\text { Publication } \\
\text { date }\end{array}$ & City & $\begin{array}{l}\text { Number of } \\
\text { pregnant } \\
\text { women }\end{array}$ & $\begin{array}{l}\text { HBsAg } \\
\text { seropositivity } \\
\text { rate (\%) }\end{array}$ \\
\hline $\begin{array}{l}\text { Bakar and } \\
\text { Dane (5) }\end{array}$ & 2016 & Istanbul & 4037 & 2.16 \\
\hline Balık et al. (6) & 2013 & Rize & 5894 & 5.7 \\
\hline $\begin{array}{l}\text { Kasap et al. } \\
\text { (9) }\end{array}$ & 2017 & Muğla & 333 & 1.8 \\
\hline $\begin{array}{l}\text { Kölgelier et } \\
\text { al. (16) }\end{array}$ & 2012 & Adıyaman & 9420 & 4.7 \\
\hline $\begin{array}{l}\text { Dağ et al. } \\
\text { (35) }\end{array}$ & 2015 & Kırıkkale & 8442 & 2.34 \\
\hline $\begin{array}{l}\text { Çiçek et al. } \\
\text { (36) }\end{array}$ & 2012 & Şanlıurfa & 56275 & 3.5 \\
\hline $\begin{array}{l}\text { Motor et al. } \\
\text { (37) }\end{array}$ & 2010 & Hatay & 13065 & 1.6 \\
\hline $\begin{array}{l}\text { Aynıoğlu et } \\
\text { al. (38) }\end{array}$ & 2015 & Zonguldak & 1084 & 4 \\
\hline $\begin{array}{l}\text { Madendağ et } \\
\text { al. (39) }\end{array}$ & 2007 & Ankara & 90531 & 2.11 \\
\hline \multicolumn{5}{|c|}{ HBsAg: Hepatitis B surface antigen } \\
\hline
\end{tabular}

conducted in Turkey over the last 20 years. In their study, they also found an HBsAg positivity rate of $2.16 \%$ in 4037 pregnant women (5). Some studies conducted in recent years on the epidemiology of hepatitis B in pregnant women in our country are reviewed in Table 2.

In our study, HBsAg seropositivity rate was found to be $1 \%$, lower than in the other studies. When the factors that may have affected this result are considered, the first thing that comes to mind is that the prevalence of hepatitis $B$, which declines over the years in the country as a whole, is a reflection on the region as well. In addition, Şırnak province is also a closed and isolated city in terms of geographical and socioeconomic aspects just like Hakkari, and a great change has recently been experienced in the population with the migration of local residents. Due to the social challenges experienced in the region, out-of-province referrals, follow-up and treatment of patients with chronic illnesses requiring further examinations have become difficult. Therefore, it is thought that the migration rate may have increased in the number of individuals with chronic diseases such as hepatitis B.

Hepatitis B vaccine has been included in the childhood vaccination program since 1998 in our country. According to the last application program, it is applied as 3 doses, in months $0,1,6$. The seropositivity rate of anti-HBs in our country also increases gradually after initiation of national hepatitis $B$ vaccination program. Dağ et al. (35) found that the rate of antiHBs positivity was $58.51 \%$ in patients aged $18-30$ years and $29.6 \%$ above in those aged 30 years and over. The decline in anti-HBs positivity rate in individuals aged 30 years and over was found to be significant. Again, Balık et al. (6) found that antiHBs rates were significantly higher in the sub-20-year-old group when compared with other age groups. Turhanoğlu et al. (29) reported that the prevalence of anti-HBs increased from $32.9 \%$ to $52.3 \%$ in Diyarbakır in an 8-year period. Anti-HBs positivity was found to be $85 \%$ in a study conducted on 556 pediatric patients aged 0-16 years who were operated for various reasons between 2008 and 2010 in Mardin (30). In our study, similar to other studies, the seroprevalence of anti-HBs was found to be $54.5 \%$ in pregnant women born after 1998, which is the time of introduction of hepatitis $B$ vaccine into routine vaccination program, and the rate was determined to be significantly higher than in the other age groups.

In studies on seroprevalence of anti-HCV performed in our country in 2011, Gönen (40) found an anti-HCV positivity rate of $0.6 \%$, Kölgelier et al. (16) found $0.28 \%$, and Madendağ et al. (39) found the rate of 0.17 . In their study conducted in Kocaeli, Çakmak et al. (41) found that the rate of anti-HCV positivity was 0.3\% in 3756 pregnant women. In their study, Dağ et al. (35) scanned 8120 pregnant women living in Kırıkkale in terms of anti$\mathrm{HCV}$, and calculated the anti-HCV seropositivity rate as $0.31 \%$ for those aged $18-30$ years and $0.59 \%$ for those older than 30 years, however, this increase was not regarded as statistically significant (35). The frequency of anti-HCV positivity in Siirt province was determined as $0.6 \%$ (26) and in Hakkari province as $1 \%$ (33). Anti$\mathrm{HCV}$ positivity was found to be $0.5 \%$ in the "Bus Project" study conducted by the VHSD (Viral Hepatitle Savaşım Derneği-Viral Hepatitis Society) between 2009 and 2011, covering all regions, primarily Eastern Anatolia and Southeastern Anatolia (22). Similar 
to other studies, anti-HCV positivity rate was found to be $0.21 \%$ in our study. These results suggest that HCV infection is not a serious and widespread problem in our country except for certain risk groups.

\section{Conclusion}

As a result, it is necessary to screen all pregnant women in our country for HBsAg and to investigate, in terms of $\mathrm{HCV}$, those who are especially suspected to be at risk. Applying hepatitis $B$ vaccination program to infants as soon as they are born, and vaccinating pregnant women with negative anti-HBs results is crucial for increasing hepatitis B immunity in the country. The decline in HBsAg seropositivity over the years after the introduction of national hepatitis B vaccination in our country is also a major indicator of the importance of vaccination.

\section{Ethics \\ Ethics Committee Approval: Retrospective study. \\ Informed Consent: Retrospective study. \\ Peer-review: Internally peer-reviewed.}

\section{Authorship Contributions}

Concept: M.Ș., Design: M.Ş., Data Collection or Processing: M.Ş., M.Z., A.A.G., B.A.P., Analysis or Interpretation: M.Ş., M.Z., Literature Search: M.Z., M.Ş., Writing: M.Z., M.Ş.

Conflict of Interest: No conflict of interest was declared by the author.

Financial Disclosure: The authors declared that this study received no financial support.

\section{References}

1. Global Hepatitis Report: Viral Hepatitis Is A Major Public Health Problem In Need Of An Urgent Response. [internet] Geneva, GA: World Health Organization. [erişim 26.10.2017].

2. Nelson PN, Jamieson DJ, Murphy TV. Prevention of Perinata Hepatitis B Virus Transmission. J Pediatric Infect Dis Soc. 2014;3(Suppl 1):7-12.

3. $\mathrm{Ni} \mathrm{YH}$. Natural history of hepatitis B virus infection: pediatric perspective. J Gastroenterol. 2011;46:1-8.

4. Xiao XM, Li AZ, Chen X, Zhu YK, Miao J. Prevention of vertical hepatitis $B$ transmission by hepatitis $B$ immunoglobulin in the third trimester of pregnancy. Int J Gynaecol Obstet. 2007;96:167170.

5. Bakar RZ, Dane B. Gebelerde hepatit B seropozitifliği ve Türk literatürüne bir bakış. Perinatoloji Dergisi 2016; 24(2): 83-88.

6. Balık G, Üstüner I, Kağıtcı M, Ural ÜM, Tekin YB, Şentürk Ş, Güven ESG, Sahin FK. Rize bölgesinde yaşayan gebe kadınlarda HBsAg, AntiHBs ve Anti-HCV seroprevalansı. Dicle Tıp Dergisi. 2013:40:254-257

7. Coşkun El, Dinçgez B, Koyucu RG, Ayanoğlu YT, Yumru AE. The Incidence of HBSAg, Anti-HBS and Anti-HCV in Pregnant Women. Perinatal Journal. 2011;19:71-75.

8. Mavilia MG, Wu GY. Mechanisms and Prevention of Vertical Transmission in Chronic Viral Hepatitis. J Clin Transl Hepatol. 2017:5:119-129.

9. Kasap B, Öner G, Küçük M, Öztürk Turhan N, Akın MN, Arıkan S, Çaylak SD. Muğla'daki gebelerin toksoplazma, rubella, sitomegalovirüs ve hepatit prevalansının değerlendirilmesi. Tepecik Eğit. ve Arașt. Hast. Dergisi. 2017;27:31-36.

10. Dunkelberg JC, Berkley EM, Thiel KW, Leslie KK. Hepatitis B and $\mathrm{C}$ in pregnancy: a review and recommendations for care. $J$ Perinatol. 2014;34:882-891.

11. Pawłowska M, Sobolewska-Pilarczyk M. Recommendations fort he management of prevention of vertical HBV and HCV infection. Przegl Epidemiol. 2016;70:33-34.

12. Kuncio DE, Newbern EC, Johnson CC, Viner KM. Failure to Test and Identify Perinatally Infected Children Born to Hepatitis C Virus-Infected Women. Clin Infect Dis. 2016;62:980-985.

13. Ahmad I. Prevalence of Hepatitis B and C Viral Infection Among Pregnant Women in Peshawar, Pakistan. Hepat Mon. 2016;16:e36383.

14. Mıstık R, Balık I. Türkiye'de viral hepatitlerin epidemiyolojik analizi. Viral Hepat J. 2003:9-55

15. Safak B. Balıkesir Atatürk Devlet Hastanesi'ne Bașvuran Hastalarda HBsAg, Anti-HCV ve AntiHIV Seroprevalansı. Viral Hepat J. 2013;19:43-45.

16. Kölgelier S, Demir LS, Aktuğ Demir N, Özçimen S, Tabak S Adıyaman Illindeki Gebelerde HBsAg ve Anti HCV Pozitifliği. Viral Hepat J. 2012;18:98-101.

17. Nüfus ve Vatandașlık Ișleri Genel Müdürlüğü: Doğum Istatistikleri 2016. [internet] Ankara, Türkiye Istatistik Kurumu [erişim 20.01.2018].

18. Cottrell EB, Chou R, Wasson N, Rahman B, Guise JM. Reducing risk for mother- to-infant transmission of hepatitis $\mathrm{C}$ virus: a systematic review for the U.S. Preventive Services Task Force. Ann Intern Med. 2013;158:109-113.

19. Wen JW, Haber BA. Maternal-fetal transmission of hepatitis C infection: what is so special about babies. J Pediatr Gastroenterol Nutr. 2014;58:278-282.

20. Tosun Yegane $S$, Erensoy $S$, Özacar T, Yücebilgin S, Bilgiç A. Gebelerin ve Bebeklerin Hepatit Virüs Infeksiyonları Yönünden Araștırılması ve Izlenmesi. Türk Mikrobiyol Cem Derg. 2003;33:153159.

21. Melek I, Aksebzeci AT, Yağmur G, Kartal B, Emiroğlu M, Erdem Y. Hastane Calıșanlarında HBV, HCV ve HIV Seropozitifliğinin Araştırılması. Türk Hij Den Biyol Derg. 2009;66:59-66.

22. Tosun S. Viral Hepatitlerin Ülkemizdeki Değişen Epidemiyolojisi. ANKEM Derg. 2013;27(Özel Sayı 2):128-134

23. Toy M, Önder FO, Wörmann T, Bozdayi AM, Schalm SW, Borsboom GJ, van Rosmalen JV, Richardus JH, Yurdaydin C. Ageand region-specific hepatitis $B$ prevalence in Turkey estimated using generalized linear mixed models: a systematic review. BMC Infect Dis. 2011:11:337.

24. Özekinci T, Atmaca S, Akpolat N, Gül K. Güneydoğu Anadolu Bölgesi'nde Rutin Hepatit B Aşı Programının Etkisi. Dicle Medical Journal. 2017:44:283-285

25. Dursun M, Ertem M, Yilmaz S, Saka G, Ozekinci T, Simsek Z. Prevalence of hepatitis $B$ infection in the southeastern region of Turkey: comparison of risk factors for HBV infection in rural and urban areas. Jpn J Infect Dis. 2005;58:15-19.

26. Tunç N, Eraydın H, Cetinkaya E, Oduncu MK, Toy Ş. Siirt Devlet Hastanesi'ne Başvuran Hastalarda HBsAg, Anti-HBs, Anti- HCV ve Anti-HIV Seroprevalansı. Viral Hepat J. 2011;17: 7-11.

27. Demirpençe Ö, Tezcan SI, Değirmen E, Mert D, Gümüş $A$, Çelen MK. Batman Devlet Hastanesine başvuran kişilerde hepatit ve HIV serolojisinin sonuçları. Viral Hepat J. 2012;18:6-10.

28. Ergunay $K$, Balaban $Y$, Cosgun $E$, Alp A, Simsek $H$, Sener $B$, Tatar G, Hascelik G. Epidemiologic trends in HBV infections at a reference centre in Turkey: an 11-year retrospective analysis. Ann Hepatol. 2012;11:672-678.

29. Turhanoğlu M, Onur A, Bilman FB, Ayaydın Z, Samancı GS. EightYear Seroprevalence of HBV, HCV and HIV in Diyarbakir Training and Research Hospital. Int J Med Sci. 2013;10:1595-1601.

30. Tekin A, Aydoğdu B. Mardin Ilinde Elektif Cerrahi Öncesi Tetkik 
Edilen Çocuklarda HBV, HCV ve HIV Seroprevalansı. Konuralp Tıp Dergisi 2011;3:7-11.

31. Aslan G, Ulukanlıgil M, Seyrek A. Şanlıurfa ilinde HBsAg, antiHBs ve anti-HCV seroprevalansı. Viral Hepat J. 2001;7:408411.

32. Sırmatel F, Yetkin G, Eriş FN, Koruk ST, Duygu F, Karaağaç L, Dinçer S. Sağlıklı Kan Donörlerinde Hepatit B Virus, Hepatit C Virus ve Hepatit D Virus Seroprevalansı.Viral Hepat J. 2012;18:1922.

33. Tekay F. Hakkâri Ilinde HBV, HCV ve HIV Seroprevalansı. Dicle Medical Journal. 2006;33:170-173.

34. Emiroğlu HH, Kesecik M, Oğuz S, Öztürk M, Nazlıgül Y, Altunay H. Şırnak'taki asker ve sivillerde asemptomatik HBV taşıyıcılığı prevalansı. Viral Hepat J. 2000;1:18-20.

35. Dağ Z, Gül S, Işık Y, Tulmaç Ö, Şimşek Y. Kırıkkale Bölgesinde Yaşayan Gebelerde Hepatit B ve Hepatit C Seropozitiflik Oranları. Bozok Tip Derg. 2015;5:1-4.

36. Çiçek AÇ, Duygu F, Inakçı IH. Şanlıurfa Ilinde Kadın Hastalıkları ve
Doğum Hastanesine Başvuran Kadınlarda Hepatit B ve Hepatit C Seroprevalansı: Üç Yıllık Değerlendirme. Viral Hepat J. 2012;18:15-18.

37. Motor VK, Evirgen Ö, Aksakal M, Inci M, Önlen Y, Ocak S. Hatay Doğum ve Çocuk Bakımevi Hastanesi'ne Başvuran Kadınlarda Hepatit B ve Hepatit C Seropozitifliği. Viral Hepat J. 2010;16:53-56.

38. Aynıoğlu A, Aynıoğlu Ö, Akar T, Aydın M, Altınok ES. HBsAg, Anti-HBs and Anti-HCV Seropositivity Rates among Pregnant Women Attending a University Hospital in Zonguldak. Viral Hepat J. 2015;21:31-34.

39. Madendağ $Y$, Madendağ IÇ, Çelen Ş, Ünlü $S$, Danışman N. Hastanemize başvuran tüm Obstetrik ve Jinekolojik hastalarda hepatit B, hepatit $\mathrm{C}$ ve HIV seroprevalansı. Türkiye Klinikleri J Gynecol Obst. 2007;17:442-446.

40. Gönen I. Kırsal kesimde gebelerde HBV ve HCV sıklığı. Viral Hepat J. 2011;17:66-68.

41. Çakmak B, Karataş A. Kocaeli Bölgesinde Yaşayan Gebe Kadınlarda Hepatit B ve C Seropozitiflik Oranları. Selçuk Tıp Dergisi. 2012;28:80-88. 